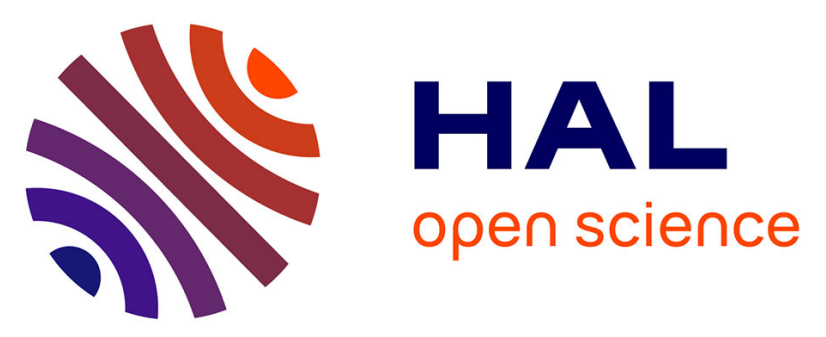

\title{
A Facile Route for the Synthesis of Polycationic Tellurium Cluster Compounds: Synthesis in Ionic Liquid Media and Characterization by Single-Crystal X-Ray Crystallography and Magnetic Susceptibility
}

Ejaz Ahmed, Eike Ahrens, Martin Heise, Michael Ruck

\section{To cite this version:}

Ejaz Ahmed, Eike Ahrens, Martin Heise, Michael Ruck. A Facile Route for the Synthesis of Polycationic Tellurium Cluster Compounds: Synthesis in Ionic Liquid Media and Characterization by Single-Crystal X-Ray Crystallography and Magnetic Susceptibility. Journal of Inorganic and General Chemistry / Zeitschrift für anorganische und allgemeine Chemie, 2010, 636 (15), pp.2602. 10.1002/zaac.201000242 . hal-00574814

\author{
HAL Id: hal-00574814 \\ https://hal.science/hal-00574814
}

Submitted on 9 Mar 2011

HAL is a multi-disciplinary open access archive for the deposit and dissemination of scientific research documents, whether they are published or not. The documents may come from teaching and research institutions in France or abroad, or from public or private research centers.
L'archive ouverte pluridisciplinaire HAL, est destinée au dépôt et à la diffusion de documents scientifiques de niveau recherche, publiés ou non, émanant des établissements d'enseignement et de recherche français ou étrangers, des laboratoires publics ou privés. 


\section{A Facile Route for the Synthesis of Polycationic Tellurium Cluster Compounds: Synthesis in Ionic Liquid Media and Characterization by Single-Crystal X-Ray Crystallography and Magnetic Susceptibility}

\begin{tabular}{|c|c|}
\hline Journal: & Zeitschrift für Anorganische und Allgemeine Chemie \\
\hline Manuscript ID: & zaac. 201000242.R1 \\
\hline Wiley - Manuscript type: & Article \\
\hline $\begin{array}{r}\text { Date Submitted by the } \\
\text { Author: }\end{array}$ & 23-Jul-2010 \\
\hline Complete List of Authors: & $\begin{array}{l}\text { Ahmed, Ejaz; Technische Universität Dresden, Fachrichtung Chemie } \\
\text { und Lebensmittelchemie } \\
\text { Ahrens, Eike; Technische Universität Dresden, Fachrichtung Chemie } \\
\text { und Lebensmittelchemie } \\
\text { Heise, Martin; Technische Universität Dresden, Fachrichtung } \\
\text { Chemie und Lebensmittelchemie } \\
\text { Ruck, Michael; Technische Universität Dresden, Fachrichtung } \\
\text { Chemie und Lebensmittelchemie }\end{array}$ \\
\hline Keywords: & $\begin{array}{l}\text { Tellurium, Polycations, Cluster compounds, Ionic Liquids, Magnetic } \\
\text { properties }\end{array}$ \\
\hline
\end{tabular}

\section{SCHOLARONE ${ }^{\text {th }}$ Manuscripts}




\title{
A Facile Route for the Synthesis of Polycationic Tellurium Cluster Compounds: Synthesis in Ionic Liquid Media and Characterization by Single-Crystal X-Ray Crystallography and Magnetic Susceptibility
}

\author{
Ejaz Ahmed, ${ }^{[a]}$ Eike Ahrens, ${ }^{[a]}$ Martin Heise, ${ }^{[a]}$ and Michael Ruck*[a]
}

Keywords: Tellurium; Polycations; Cluster compounds; Ionic Liquids; Magnetic properties

\begin{abstract}
An innovative soft chemical approach has been applied, using ionic liquids as an alternative reaction medium for the synthesis of tellurium polycationic cluster compounds at room temperature. $\quad\left[\mathrm{Mo}_{2} \mathrm{Te}_{12}\right] \mathrm{I}_{6}, \quad \mathrm{Te}_{6}\left[\mathrm{WOCl}_{4}\right]_{2}$, and $\mathrm{Te}_{4}\left[\mathrm{AlCl}_{4}\right]_{2}$ have been isolated from the ionic liquid [BMIM]Cl/ $/ \mathrm{AlCl}_{3}$ ([BMIM] $]^{+}:$1-n-butyl-3methylimidazolium) and characterized. Black, cube-shaped crystals of $\left[\mathrm{Mo}_{2} \mathrm{Te}_{12}\right] \mathrm{I}_{6}$, which is not accessible by conventional chemical transport reaction, are obtained by reacting the elements at room temperature in $[\mathrm{BMIM}] \mathrm{Cl} / \mathrm{AlCl}_{3}$. The monoclinic structure $\left(P 2{ }_{1} / n, a=1138.92(2) \mathrm{pm}, b\right.$ $=1628.13(2) \mathrm{pm}, c=1611.05(2) \mathrm{pm}, \beta=$ $\left.105.88(1)^{\circ}\right)$ is homeotypic to the triclinic bromide
\end{abstract}

\section{Introduction}

The formation of polycationic clusters in Lewis acid is a well-known feature of tellurium chemistry. $\mathrm{Te}_{4}{ }^{2+}, \mathrm{Te}_{6}{ }^{4+}, \mathrm{Te}_{6}{ }^{2+}, \mathrm{Te}_{8}{ }^{2+}, \mathrm{Te}_{7}{ }^{2+}$, and $\mathrm{Te}_{10}{ }^{2+}$ have been structurally characterized [1]. There are three different routes for the synthesis of tellurium polycationic clusters in literature: The classical route, performed by Gillespie and coworkers, is the oxidation of tellurium by $\mathrm{AsF}_{5}$ or $\mathrm{SbF}_{5}$ in liquid $\mathrm{SO}_{2}$ using a temperature range from $-196{ }^{\circ} \mathrm{C}$ to $25^{\circ} \mathrm{C}$ [2]. High temperature synthesis was carried out by Corbett et al. [3] and Beck et al. [1]. Kloo and co-workers introduced the first room temperature synthesis using $\mathrm{Ga}_{3}$-benzene media $(X=\mathrm{Br}, \mathrm{Cl})[4]$.

\footnotetext{
* Prof. Dr. Michael Ruck

Fax: (+49) 351-463-37287

E-mail: Michael.Ruck@tu-dresden.de

[a] Professur für Anorganische Chemie II

Technische Universität Dresden

D-01062 Dresden, Germany.
}

Supporting information for this article is available on the WWW under http://dx.doi.org/10.1002/zaac201000xxx
$\left[\mathrm{Mo}_{2} \mathrm{Te}_{12}\right] \mathrm{Br}_{6}$. In the binulear complex $\left[\mathrm{Mo}_{2} \mathrm{Te}_{12}\right]^{6+}$, the molybdenum(III) atoms are $\eta^{4}$-coordinated by terminal $\mathrm{Te}_{4}{ }^{2+}$ rings and two bridging $\eta^{2}-\mathrm{Te}_{2}{ }^{2-}$ dumbbells. Despite the short Mo $\cdots$ Mo distance of 297.16(5) pm, coupling of the magnetic moments is not observed. The paramagnetic moment of 3.53 $\mu_{\mathrm{B}}$ per molybdenum(III) atom corresponds to an electron count of seventeen. Black crystals of monoclinic $\mathrm{Te}_{6}\left[\mathrm{WOCl}_{4}\right]_{2}$ are obtained by the oxidation of tellurium with $\mathrm{WOCl}_{4}$ in $[\mathrm{BMIM}] \mathrm{Cl} / \mathrm{AlCl}_{3}$. Tellurium and tellurium(IV) synproportionate in the ionic liquid at room temperature yielding violet crystals of orthorhombic $\mathrm{Te}_{4}\left[\mathrm{AlCl}_{4}\right]_{2}$.

Recently, we have reported a new room temperature route for the synthesis of bismuth polycationic clusters from ionic liquids and anticipated that this approach can be extended to other elements of the periodic table, e.g. tellurium [5].

The key factors of this new synthetic route are:

i) Very high solubility of the elements $(\mathrm{Bi}, \mathrm{Te}$, $\mathrm{Sb}, \mathrm{Se}, \mathrm{Ga}, \mathrm{In}$ ) and their halogenides at room temperature allow reactions under mild conditions involving one-pot synthesis.

ii) Low temperature synthesis eliminates the risk of product decomposition.

iii) Easier reproducibility of the products.

iv) Controllable parameters, such as solvent acidity, oxidizing/reducing agent, or halide acceptor, allow modifying the synthesis with the objective to crystallize different products.

The application of this approach in order to synthesize tellurium cluster compounds at room temperature resulted in the isolation of $\left[\mathrm{Mo}_{2} \mathrm{Te}_{12}\right] \mathrm{I}_{6}, \mathrm{Te}_{4}\left[\mathrm{AlCl}_{4}\right]_{2}$, and $\mathrm{Te}_{6}\left[\mathrm{WOCl}_{4}\right]_{2}$. 


\section{Results and Discussions}

\section{Synthesis and Structure of $\left[\mathrm{Mo}_{2} \mathrm{Te}_{12}\right] \mathrm{I}_{6}$}

$\left[\mathrm{Mo}_{2} \mathrm{Te}_{12}\right] \mathrm{I}_{6}$ is homeotypic to $\left[\mathrm{Mo}_{2} \mathrm{Te}_{12}\right] \mathrm{Br}_{6}$ containing a heteropolycationic $\left[\mathrm{Mo}_{2} \mathrm{Te}_{12}\right]^{6+}$ cluster. $\left[\mathrm{Mo}_{2} \mathrm{Te}_{12}\right] \mathrm{Br}_{6}$ was synthesized by Beck through chemical vapor transport (CVT) [6a]. He used a temperature gradient of $340{ }^{\circ} \mathrm{C}$ to $270{ }^{\circ} \mathrm{C}$ to get single-crystals of $\left[\mathrm{Mo}_{2} \mathrm{Te}_{12}\right] \mathrm{Br}_{6}$ within four weeks. Despite many attempts, the CVT synthesis of the analogous iodide failed [7]. In our studies, $\left[\mathrm{Mo}_{2} \mathrm{Te}_{12}\right] \mathrm{I}_{6}$ was obtained by reacting $\mathrm{Mo}$, Te and $\mathrm{I}_{2}$ in the Lewis acidic ionic liquid [BMIM]Cl/ $/ \mathrm{AlCl}_{3}$ at room temperature to give a dark solution within minutes. After overnight stirring and a crystallization period of only three days, singlecrystals could be isolated with a yield of $35 \%$.

The monoclinic cell (space group $P 2{ }_{1} / n$ ) contains four formula units. The cationic complex $\left[\mathrm{Mo}_{2} \mathrm{Te}_{12}\right]^{6+}$ has a pair of molybdenum atoms, which are connected by two bridging $\eta^{2}-\mathrm{Te}_{2}{ }^{2-}$ groups (Figure 1). In addition, each molybdenum atom is coordinated by a terminal polycationic $\mathrm{Te}_{4}{ }^{2+}$ ligand in $\eta^{4}$ mode. As a result, both molybdenum atoms are in square-antiprismatic environment.

Figure 1. $\left[\mathrm{Mo}_{2} \mathrm{Te}_{12}\right]^{6+}$ complex cation. The ellipsoids represent $95 \%$ probability at $150(2) \mathrm{K}$.

The point symmetry of the $\left[\mathrm{Mo}_{2} \mathrm{Te}_{12}\right]^{6+}$ complex in both compounds, i.e. in monoclinic $\left[\mathrm{Mo}_{2} \mathrm{Te}_{12}\right] \mathrm{I}_{6}$ and in triclinic $\left[\mathrm{Mo}_{2} \mathrm{Te}_{12}\right] \mathrm{Br}_{6}$, is close to $D_{2 \mathrm{~h}}(\mathrm{mmm})$, although the site symmetry of the cluster is $C_{i}$ in the bromide and $C_{s}$ in the iodide. Moreover, there is only one independent complex present in the unit cell of $\left[\mathrm{Mo}_{2} \mathrm{Te}_{12}\right] \mathrm{I}_{6}$ whereas two independent complexes are found in $\left[\mathrm{Mo}_{2} \mathrm{Te}_{12}\right] \mathrm{Br}_{6}$.

The distances between molybdenum and tellurium atoms of the $\mathrm{Te}_{2}{ }^{2-}$ groups are slightly shorter (272.35(4) pm to 274.41(4) pm) than those between molybdenum and tellurium atoms of the $\mathrm{Te}_{4}{ }^{2+}$ rings $(278.99(5) \mathrm{pm}$ to $285.38(4) \mathrm{pm})$. The $\mathrm{Te}_{4}{ }^{2+}$ rings show significant distortion (distances: 276.12(5) pm to 286.85(4) pm, angles: 87.19(1) ${ }^{\circ}$ to $92.61(1)^{\circ}$ ) from $D_{4 \mathrm{~h}}$ to butterfly conformation with dihedral angles $5.3^{\circ}$ and $5.9^{\circ}$ (Table 1).

The complexes $\left[\left(\mathrm{Mo}^{3+}\right)_{2}\left(\mathrm{Te}_{2}{ }^{2-}\right)_{2}\left(\mathrm{Te}_{4}{ }^{2+}\right)_{2}\right]^{6+}$ are surrounded by iodide ions, which connect them into layers (Figure 2). The shortest distance between an iodide ion and an atom of the $\mathrm{Te}_{4}{ }^{2+}$ rings is $302.20(4) \mathrm{pm}$.

Figure 2. Section of the crystal structure of $\left[\mathrm{Mo}_{2} \mathrm{Te}_{12}\right] \mathrm{I}_{6}$. The ellipsoids represent $95 \%$ probability at $150(2) \mathrm{K}$.

$\left[\mathrm{Mo}_{2} \mathrm{Te}_{12}\right] \mathrm{I}_{6}$ is paramagnetic with Weiss temperature $\theta=+5.8 \mathrm{~K}$ (Figure 3 ). An analysis based on the Curie-Weiss law gives a paramagnetic effective moment of $3.53 \mu_{\mathrm{B}}$ per molybdenum atom, which is slightly lower than the spin-only value of $3.87 \mu_{\mathrm{B}}$ for a $\mathrm{d}^{3}$ configuration. In low fields some traces of ferromagnetism are found but these are very weak and most probably due to minor impurity phases.

The absence of intramolecular coupling of the magnetic cations in $\left[\mathrm{Mo}_{2} \mathrm{Te}_{12}\right] \mathrm{I}_{6}$ is astonishing, since the short distance of 297.16(5) pm between the molybdenum(III) atoms suggests a chemical bond. In the present case the complex is a diradical with seventeen electrons per central atom. The electron counting scheme adds up the three valence electrons of a molybdenum(III) atom, six electrons of the $\pi$-system of the $\mathrm{Te}_{4}{ }^{2+}$ ring, and four electrons (two lone-pairs) of each $\mathrm{Te}_{2}{ }^{2-}$ group $(3+6+4 \cdot 2=$ $17)$.

In contrast, the closely related catenacompound $\mathrm{MoTe}_{4} \mathrm{Br}=\left[\left(\mathrm{Mo}^{3+}\right)_{2}\left(\mathrm{Te}_{2}{ }^{2-}\right)_{2}\left(\mathrm{Te}_{2} \mathrm{Br}^{-}\right)_{2}\right]$ with a Mo-Mo bond length of 300.5(2) pm shows only weak, nearly temperature-independent paramagnetism with a magnetic moment of $0.4 \mu_{\mathrm{B}}$ at $310 \mathrm{~K}$, indicating a strong coupling and an eighteen electron situation [6a].

Figure 3. Temperature dependence of reciprocal molar susceptibility for $\left[\mathrm{Mo}_{2} \mathrm{Te}_{12}\right] \mathrm{I}_{6}$ in a magnetic field of $H=35 \mathrm{kOe}$.

\section{Synthesis and Structure of $\mathrm{Te}_{4}\left[\mathrm{AlCl}_{4}\right]_{2}$}

$\mathrm{Te}_{4}\left[\mathrm{AlCl}_{4}\right]_{2}$ was reported by Corbett and coworkers through synproportionation at $250{ }^{\circ} \mathrm{C}$ [3]. Contrary to higher temperature method, we obtained $\mathrm{Te}_{4}\left[\mathrm{AlCl}_{4}\right]_{2}$ by reacting $\mathrm{Te}$ and $\mathrm{TeCl}_{4}$ in the Lewis acidic ionic liquid $[\mathrm{BMIM}] \mathrm{Cl} / \mathrm{AlCl}_{3}$ at room temperature. Addition of a small amount of 
anhydrous $\mathrm{NaCl}$ is helpful for getting single crystals in two days (66 \% yield). The orthorhombic compound contains planar $\mathrm{Te}_{4}{ }^{2+}$ polycations and tetrahedral $\mathrm{AlCl}_{4}^{-}$anions. The atomic coordinates agree within three standard deviations with those published earlier [3].

\section{Synthesis and Structure of $\mathrm{Te}_{6}\left[\mathrm{WOCl}_{4}\right]_{2}$}

Crystals of $\mathrm{Te}_{6}\left[\mathrm{WOCl}_{4}\right]_{2}$ have previously been synthesized within two weeks using CVT in the temperature gradient of $230{ }^{\circ} \mathrm{C}$ to $210{ }^{\circ} \mathrm{C}$ [6b]. We carried out the oxidation of elemental tellurium with $\mathrm{WOCl}_{4}$ in ionic liquids at room temperature. Addition of anhydrous $\mathrm{NaCl}$ to the dark coloured filtrate resulted in precipitation of black crystals in three days (yield: $39 \%$ ).

The crystal structure consists of boat shaped $\mathrm{Te}_{6}{ }^{2+}$ polycations and one-dimensional squarepyramidal $\mathrm{WOCl}_{4}{ }^{-}$anions. The atomic coordinates agree within six standard deviations with those published by Beck [6b].

\section{Conclusion}

We have developed an ionic-liquid-based room-temperature synthesis of homo- and heteropolyatomic cluster compounds. The significance of the present study is manifold. The redox reactions in ionic liquids provide an efficient, one-step route to the inorganic clusters. Salting out is quite helpful technique to get single crystals in few days. The additional advantages of this synthetic route are:

i) Inclusion of the organic cation has not been observed yet.

ii) Ionic liquids render stability to the ionic intermediates [5].

iii) Reactions are faster and there is no need to wait for weeks as in chemical vapor transport (CVT). Crystal growth requires only few days, and the yields can be rather high.

iv) Moreover, ionic liquids are regarded as economical and environmental friendly solvents. They could be alternatives to cancer causing organic solvents [8].

These features make the soft chemical procedure a versatile and general route towards the synthesis of other innovative materials.

\section{Experimental Section}

Chemicals: Starting materials were commercial 1methylimidazole (Merck, $99 \%$ ), 1-chlorobutane (Merck, $98.5 \%$ ), $\mathrm{AlCl}_{3}$ (Fluka, anhydrous, 98\%), Te (Aldrich, $99.999 \%$ ), $\mathrm{WOCl}_{4}$ (Aldrich, $98 \%$ ), Mo (Aldrich, $99.95 \%$ ), $\mathrm{I}_{2}$ (Grüssing, $99.5 \%$ ), and $\mathrm{Cl}_{2}$ (Air Liquide, $99.8 \%$ ). $\mathrm{TeCl}_{4}$ was synthesized from the elements [9]. $\mathrm{AlCl}_{3}$ was sublimated three times. $\mathrm{I}_{2}$ was sublimated twice over $\mathrm{BaO}$. Organic reagents were distilled before use. Because of the high moisture sensitivity of the anhydrous metal halides used in this work, all manipulations were performed under dry argon (99.999\%) atmosphere in standard Schlenk tubes.

Synthesis of $\left[\mathrm{Mo}_{2} \mathrm{Te}_{12}\right] \mathrm{I}_{6}:$ The ionic liquid $[\mathrm{BMIM}] \mathrm{Cl} / \mathrm{AlCl}_{3} \quad\left([\mathrm{BMIM}]^{+}:\right.$1-n-butyl-3methylimidazolium) were prepared according to a literature procedure [10]. The starting materials were added together in the Lewis acidic $[\mathrm{BMIM}] \mathrm{Cl} / \mathrm{AlCl}_{3}$ ionic liquid (molar ratio = 1:1.3, volume $=1.5 \mathrm{ml}$ ) having molar ratio of Mo:Te: $\mathrm{I}=$ 1:6:3 (total mass $=355 \mathrm{mg}$ ). The reaction mixture was left for stirring overnight at room temperature. After three days, black, cube-shaped crystals were obtained. Yield: $35 \%$. The energy-dispersive Xray (EDX) analysis of a single crystal gave the atomic ratio Mo:Te:I = 10:55:35 (expected $=$ 10:60:30). EDX is only a semiquantitative technique, which sometimes cannot give exact estimation for two closely related elements.

Synthesis of $\mathrm{Te}_{4}\left[\mathrm{AlCl}_{4}\right]_{2}$ : The stoichiometric amount of $\mathrm{Te}$ and $\mathrm{TeCl}_{4}$ (total mass $=260 \mathrm{mg}$ ) were added to the Lewis acidic [BMIM]Cl/AlCl ${ }_{3}$ $($ molar ratio $=1: 1.3$, volume $=1.5 \mathrm{ml})$ ionic liquid . The reaction mixture was left for stirring overnight at room temperature then filtered to separate unreacted material. Addition of a small amount of anhydrous $\mathrm{NaCl}$ into the dark violet filtrate led to the precipitation of violet, column-like crystals in two days. Yield: $66 \%$. EDX: Te:Al:Cl = 27:15:58 $($ expected $=29: 14: 57)$.

Synthesis of $\mathrm{Te}_{6}\left[\mathrm{WOCl}_{4}\right]_{2}$ : The same procedure was used as described for $\mathrm{Te}_{4}\left[\mathrm{AlCl}_{4}\right]_{2}$, starting from $\mathrm{Te}$ and $\mathrm{WOCl}_{4}$ (total mass $=288 \mathrm{mg}$ ). After three days, black, irregular shaped crystals were obtained. Yield: $39 \%$. Because of the high moisture sensitivity of $\mathrm{Te}_{6}\left[\mathrm{WOCl}_{4}\right]_{2}$, it was not yet possible to carry out EDX analysis. 
X-Ray Crystallography: Since all compounds are sensitive towards hydrolysis by moist air, crystals were selected in a glove box (concentration of $\mathrm{O}_{2}<$ $0.1 \mathrm{ppm}$ and $\mathrm{H}_{2} \mathrm{O}<0.1 \mathrm{ppm}$ ) and filled in glass capillaries of $0.2 \mathrm{~mm}$ diameter, which were sealed by a hot filament in the argon atmosphere. Intensity data of a single-crystal of $\left[\mathrm{Mo}_{2} \mathrm{Te}_{12}\right] \mathrm{I}_{6}$ were recorded using a Bruker Kappa CCD diffractometer and graphite-monochromatized Mo$K \alpha$ radiation $(\lambda=71.073 \mathrm{pm})$ at $150 \mathrm{~K}$. Data sets of single-crystals of $\mathrm{Te}_{4}\left[\mathrm{AlCl}_{4}\right]_{2}$ and $\mathrm{Te}_{6}\left[\mathrm{WOCl}_{4}\right]_{2}$ were collected on an imaging-plate diffraction system IPDS-I (Stoe) using graphitemonochromatized Mo-K $\alpha$ radiation at room temperature. The raw data were corrected for background, polarization and the Lorentz factor. The microscopic description of the crystal shapes, which was later used in the numerical absorption corrections [11], was optimized using sets of reflections that are equivalent in the monoclinic Laue class for $\left[\mathrm{Mo}_{2} \mathrm{Te}_{12}\right] \mathrm{I}_{6}$ and $\mathrm{Te}_{6}\left[\mathrm{WOCl}_{4}\right]_{2}$, orthorhombic for $\mathrm{Te}_{4}\left[\mathrm{AlCl}_{4}\right]_{2}[12]$. The structures were solved with direct methods and refined using SHELX97 [13]. After refinement of the structure model of $\left[\mathrm{Mo}_{2} \mathrm{Te}_{12}\right] \mathrm{I}_{6}$, we found a residual electron density of $+5.08 \mathrm{e} \cdot 10^{-6} \mathrm{pm}^{-3}$ which can be interpreted as a second orientation of the $\mathrm{Te}_{4}{ }^{2+}$ rings with weight of a few percents. This disorder could not be refined neither in a split atom model nor in a twin model. Slow cooling of the crystals did not lead to ordering. Graphics of the structures were developed using the program Diamond 3.2e [14]. The results of the structure determinations are summarized in Tables 2 and 3. Further crystal structure data have been deposited at the Fachinformationszentrum Karlsruhe, D-76344 Eggenstein-Leopoldshafen, Germany (Fax: +497247-808-666, E-Mail: crysdata@ fiz-karlsruhe.de). Inquiries should be accompanied by the depository number CSD-421881 $\left(\left[\mathrm{Mo}_{2} \mathrm{Te}_{12}\right] \mathrm{I}_{6}\right), \mathrm{CSD}-421883$ $\left(\mathrm{Te}_{4}\left[\mathrm{AlCl}_{4}\right]_{2}\right)$, and CSD-421882 $\left(\mathrm{Te}_{6}\left[\mathrm{WOCl}_{4}\right]_{2}\right)$.

Magnetic Susceptibility Measurements: The magnetic susceptibility of $\left[\mathrm{Mo}_{2} \mathrm{Te}_{12}\right] \mathrm{I}_{6}$ was measured with a SQUID magnetometer (MPMSXL7, Quantum Design) between $1.8 \mathrm{~K}$ and $400 \mathrm{~K}$ of a $50 \mathrm{mg}$ sample in four different magnetic fields between 0.10 and $70 \mathrm{kOe}$.

Supporting information: Structural parameters for $\mathrm{Te}_{4}\left[\mathrm{AlCl}_{4}\right]_{2}$ and $\mathrm{Te}_{6}\left[\mathrm{WOCl}_{4}\right]_{2}$, as well as data of the temperature dependence of the reciprocal molar susceptibility for $\left[\mathrm{Mo}_{2} \mathrm{Te}_{12}\right] \mathrm{I}_{6}$ in different magnetic fields are available on internet http://dx.doi.org/10.1002/zaac.

Acknowledgments. We thank Dr. W. Schnelle (Max Planck Institute for Chemical Physics of Solids, Dresden) for performing magnetic susceptibility measurements and Prof. Dr. J. Beck (University of Bonn) for helpful discussions. The authors also gratefully acknowledge the Higher Education Commission of Pakistan and the German Academic Exchange Service (DAAD) for financial support.

\section{References}

[1] a) J. Beck, Angew. Chem. 1994, 106, 172182; Angew. Chem. Int. Ed. Engl. 1994, 33, 163-172; b) J. Beck, Coord. Chem. Rev. 1997, 163, 55-70.

[2] a) R. C. Burns, R. J. Gillespie, W. C. Luk, D. R. Slim, Inorg. Chem. 1979, 18, 3086-3094; b) G. Cardinal, R. J. Gillespie, J. F. Sawyer, J. E. Vekris, J. Chem. Soc. Dalton Trans. 1982, 765-799; c) M. J. Collins, R. J. Gillespie, J. F. Sawyer, Inorg. Chem. 1987, 26, 14761481; d) R. C. Burns, M. J. Collins, S. M. Eicher, R. J. Gillespie, J. F. Sawyer, Inorg. Chem. 1988, 27, 1807-1813.

[3] T. W. Couch, D. A. Lokken, J. D. Corbett, Inorg. Chem. 1972, 11, 357-362.

[4] a) M. Lindsjö, L. Kloo, Acta Crystallogr. 2005, E61, i18-i19; b) A. N. Kuznetsov, B. A. Popovkin, K. Ståhl, M. Lindsjö, L. Kloo, Eur. J. Inorg. Chem. 2005, 4907-4913.

[5] E. Ahmed, D. Köhler, M. Ruck, Z. Anorg. Allg. Chem. 2009, 635, 297-300.

[6] a) J. Beck, J. Solid State. Chem. 1996, 125, 165-170; b) J. Beck, Chem. Ber. 1995, 128, 23-27.

[7] J. Beck, private communication.

[8] C. L. Hussey, Pure \& Appl. Chem. 1988, 60, 1763-1772; b) J. Wright, Environmental Chemistry, Taylor Francis, New York, 2003, pp. 74, 208.

[9] G. Brauer, Handbuch der Präparativen Anorganischen Chemie, Ferdinand Enke, Stuttgart, 1975, p. 432.

[10] J. S. Wilkes, J. A. Levisky, R. A. Wilson, C. L. Hussey, Inorg. Chem. 1982, 21, 12631264. 
[11] X-RED32, Data Reduction Program, Version 1.01, Stoe \& Cie GmbH, Darmstadt, 2001.

[12] X-SHAPE, Crystal Optimisation for Numerical Absorption Correction Program, Version 1.06, Stoe \& Cie GmbH, Darmstadt, 1999.

[13] a) G. M. Sheldrick, SHELX97, Programs for crystal structure determination, Univ. of Göttingen, 1997; b) G. M. Sheldrick, Acta Crystallogr. 2008, A64, 112-122.

[14] K. Brandenburg, Diamond 3.2e, Crystal and Molecular Structure Visualization, Crystal Impact GbR, Bonn, 2010. 
Table 1. Selected interatomic distances $(\mathrm{pm})$ in $\left[\mathrm{Mo}_{2} \mathrm{Te}_{12}\right] \mathrm{I}_{6}$.

\begin{tabular}{|c|c|c|c|c|c|}
\hline atoms & & distance & atoms & & distance \\
\hline \multirow[t]{3}{*}{ Te1- } & $\mathrm{Te} 2$ & $286.85(4)$ & Te7- & Te8 & $276.81(4)$ \\
\hline & $\mathrm{Te} 4$ & $276.97(4)$ & & Mo1 & $272.73(4)$ \\
\hline & Mo1 & $284.54(4)$ & & Mo2 & 273.71(4) \\
\hline \multirow[t]{3}{*}{ Te2- } & $\mathrm{Te} 3$ & 276.93(4) & Te8- & Mo1 & $273.10(4)$ \\
\hline & Mo1 & $280.18(4)$ & & Mo2 & $273.49(4)$ \\
\hline & I2 & $302.20(4)$ & Te9- & Te10 & $283.07(5)$ \\
\hline \multirow[t]{2}{*}{ Te3- } & $\mathrm{Te} 4$ & $280.66(4)$ & & $\mathrm{Te} 12$ & $276.12(5)$ \\
\hline & Mo1 & $284.54(4)$ & & Mo2 & $285.38(4)$ \\
\hline Te4- & Mo1 & $280.24(4)$ & Te10- & Te11 & $276.91(5)$ \\
\hline \multirow[t]{3}{*}{ Te5- } & Te6 & $276.71(4)$ & & Mo2 & $279.97(5)$ \\
\hline & Mo1 & $274.05(4)$ & & I6 & $314.77(5)$ \\
\hline & Mo2 & $274.41(4)$ & Te11- & Te12 & $281.18(5)$ \\
\hline \multirow[t]{3}{*}{ Te6- } & Mo1 & $273.22(4)$ & & Mo2 & $284.43(5)$ \\
\hline & Mo2 & $272.35(4)$ & Te12- & Mo2 & $278.99(5)$ \\
\hline & & & Mo1- & Mo2 & $297.16(5)$ \\
\hline
\end{tabular}

Table 2. Crystallographic data and details of the structure determinations for $\left[\mathrm{Mo}_{2} \mathrm{Te}_{12}\right] \mathrm{I}_{6}, \mathrm{Te}_{4}\left[\mathrm{AlCl}_{4}\right]_{2}$, and $\mathrm{Te}_{6}\left[\mathrm{WOCl}_{4}\right]_{2}$.

\begin{tabular}{|c|c|c|c|}
\hline Compound & {$\left[\mathrm{Mo}_{2} \mathrm{Te}_{12}\right] \mathrm{I}_{6}$} & $\mathrm{Te}_{4}\left[\mathrm{AlCl}_{4}\right]_{2}$ & $\mathrm{Te}_{6}\left[\mathrm{WOCl}_{4}\right]_{2}$ \\
\hline Crystal system & monoclinic & orthorhombic & monoclinic \\
\hline Space group & $P 2_{1} / n$ & Pbca & $P 2{ }_{1} / c$ \\
\hline Temperature $(\mathrm{K})$ & $150(2)$ & 293(2) & 293(2) \\
\hline$a, b, c(\mathrm{pm}), \beta\left(^{\circ}\right)$ & $\begin{array}{l}\text { 1138.92(2), 1628.13(2), } \\
1611.05(2), 105.88(1)\end{array}$ & $\begin{array}{l}\text { 1072.1(1), 1412.8(1), } \\
1183.2(2), 90\end{array}$ & $\begin{array}{l}917.07(8), 1631.9(2), \\
3077.5(3), 117.008(7)\end{array}$ \\
\hline$V\left(10^{6} \mathrm{pm}^{3}\right)$ & $2873.42(7)$ & $1792.1(4)$ & $4103.4(7)$ \\
\hline Formula units per cell & 4 & 4 & 8 \\
\hline Calculated density $\left(\mathrm{g} \cdot \mathrm{cm}^{-3}\right)$ & 5.74 & 3.14 & 4.69 \\
\hline Measurement device & CCD Kappa (Bruker) & \multicolumn{2}{|c|}{ imaging plate diffractometer (IPDS-I, Stoe) } \\
\hline Radiation & \multicolumn{3}{|c|}{ graphite-monochromated Mo- $K \alpha$ radiation $(\lambda=71.073 \mathrm{pm})$} \\
\hline \multirow{3}{*}{ Measurement range } & $-17 \leq h \leq 17$ & $-11 \leq h \leq 11$ & $-9 \leq h \leq 9$ \\
\hline & $-27 \leq k \leq 26$ & $-14 \leq k \leq 14$ & $-18 \leq k \leq 18$ \\
\hline & $-27 \leq l \leq 26$ & $-12 \leq l \leq 12$ & $-34 \leq l \leq 34$ \\
\hline$\mu(\mathrm{Mo}-K \alpha)\left(\mathrm{mm}^{-1}\right)$ & 19.25 & 7.70 & 20.60 \\
\hline Measured reflections & 72507 & 8267 & 23195 \\
\hline Unique reflections $F_{\mathrm{o}}>4 \sigma\left(F_{\mathrm{o}}\right)$ & 13529,9970 & 1106,868 & 5789,3911 \\
\hline$R($ int $), R(\sigma)$ & $0.041,0.039$ & $0.079,0.038$ & $0.086,0.066$ \\
\hline$R_{l}\left[F_{\mathrm{o}}>4 \sigma\left(F_{\mathrm{o}}\right)\right]$ & 0.035 & 0.033 & 0.063 \\
\hline$R_{l}\left(\right.$ all $\left.F_{\mathrm{o}}\right)$ & 0.060 & 0.050 & 0.103 \\
\hline$w R_{2}\left(\right.$ all $\left.F_{\mathrm{o}}{ }^{2}\right)$ & 0.060 & 0.066 & 0.070 \\
\hline No. of parameters & 182 & 64 & 305 \\
\hline Goodness of fit & 1.27 & 1.20 & 1.27 \\
\hline$\Delta \rho(\max , \min )\left(\mathrm{e} \cdot 10^{-6} \mathrm{pm}^{-3}\right)$ & $+5.08,-4.31$ & $+0.86,-0.76$ & $+1.33,-1.23$ \\
\hline
\end{tabular}


2

4

5

6

7

8

9

10

11

12

13

14

15

16

17

18

19

20

21

22

23

24

25

26

27

28

29

30

31

32

33

34

35

36

37

38

39

40

41

42

43

44

45

46

47

48

49

50

51

52

53

54

55

56

57

58

59

60

Table 3. Coordinates and equivalent isotropic displacement parameters for $\left[\mathrm{Mo}_{2} \mathrm{Te}_{12}\right] \mathrm{I}_{6}$ at $150(2) \mathrm{K}$. All atoms occupy Wyckoff positions $4 e$. $U_{\text {eq }}$ is defined as one third of the trace of the orthogonalized $U_{\mathrm{ij}}$ tensor.

\begin{tabular}{lllll}
\hline Atom & $x$ & $y$ & $z$ & $U_{\text {eq }} / \mathrm{pm}^{2}$ \\
\hline Te1 & $0.31709(3)$ & $0.37043(2)$ & $0.17595(2)$ & $131.6(6)$ \\
Te2 & $0.36271(3)$ & $0.38843(2)$ & $0.35915(2)$ & $146.1(6)$ \\
Te3 & $0.27428(3)$ & $0.54712(2)$ & $0.32742(2)$ & $155.6(6)$ \\
Te4 & $0.20828(3)$ & $0.52383(2)$ & $0.14798(2)$ & $155.9(6)$ \\
Te5 & $-0.02771(3)$ & $0.34316(2)$ & $0.10664(2)$ & $155.7(6)$ \\
Te6 & $0.07955(3)$ & $0.24667(2)$ & $0.24851(2)$ & $145.1(6)$ \\
Te7 & $0.03788(3)$ & $0.41154(2)$ & $0.39261(2)$ & $164.7(6)$ \\
Te8 & $-0.07073(3)$ & $0.50746(2)$ & $0.25047(2)$ & $160.4(6)$ \\
Te9 & $-0.26539(3)$ & $0.20622(2)$ & $0.17358(2)$ & $176.9(6)$ \\
Te10 & $-0.19369(3)$ & $0.23018(2)$ & $0.35450(2)$ & $207.7(7)$ \\
Te11 & $-0.30688(3)$ & $0.38207(2)$ & $0.32504(2)$ & $188.6(7)$ \\
Te12 & $-0.35434(3)$ & $0.36452(2)$ & $0.14525(2)$ & $188.0(6)$ \\
Mo1 & $0.12620(3)$ & $0.41140(2)$ & $0.25141(2)$ & $73.4(6)$ \\
Mo2 & $-0.11637(3)$ & $0.34246(2)$ & $0.24880(2)$ & $71.9(6)$ \\
I1 & $0.42135(3)$ & $0.20062(2)$ & $0.28829(2)$ & $171.5(6)$ \\
I6 & $0.36168(3)$ & $0.43821(2)$ & $0.53966(2)$ & $227.0(7)$ \\
I5 & $-0.16105(3)$ & $0.44977(2)$ & $-0.04292(2)$ & $235.9(7)$ \\
\hline & $-0.33000(3)$ & $0.29032(2)$ & $-0.04388(2)$ & $191.8(6)$ \\
I6 & $-0.07943(3)$ & $0.05472(2)$ & $0.29289(2)$ & $172.1(6)$ \\
I & $-0.14299(4)$ & $0.32255(2)$ & $0.53245(2)$ & $282.7(8)$ \\
\hline
\end{tabular}




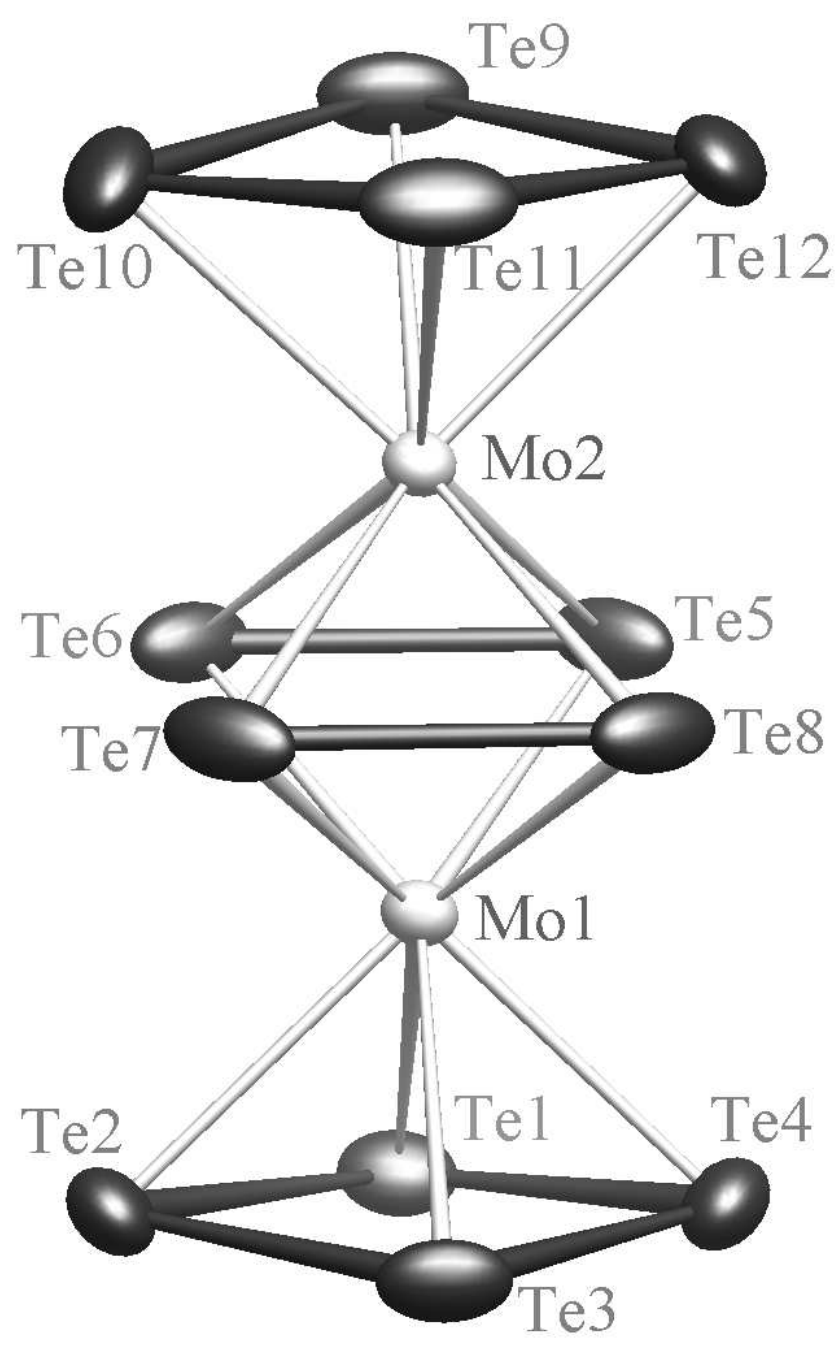

$\left[\mathrm{Mo}_{2} \mathrm{Te}_{12}\right]^{6+}$ complex cation. The ellipsoids represent $95 \%$ probability at $150(2) \mathrm{K}$. $265 \times 281 \mathrm{~mm}(96 \times 96 \mathrm{DPI})$ 


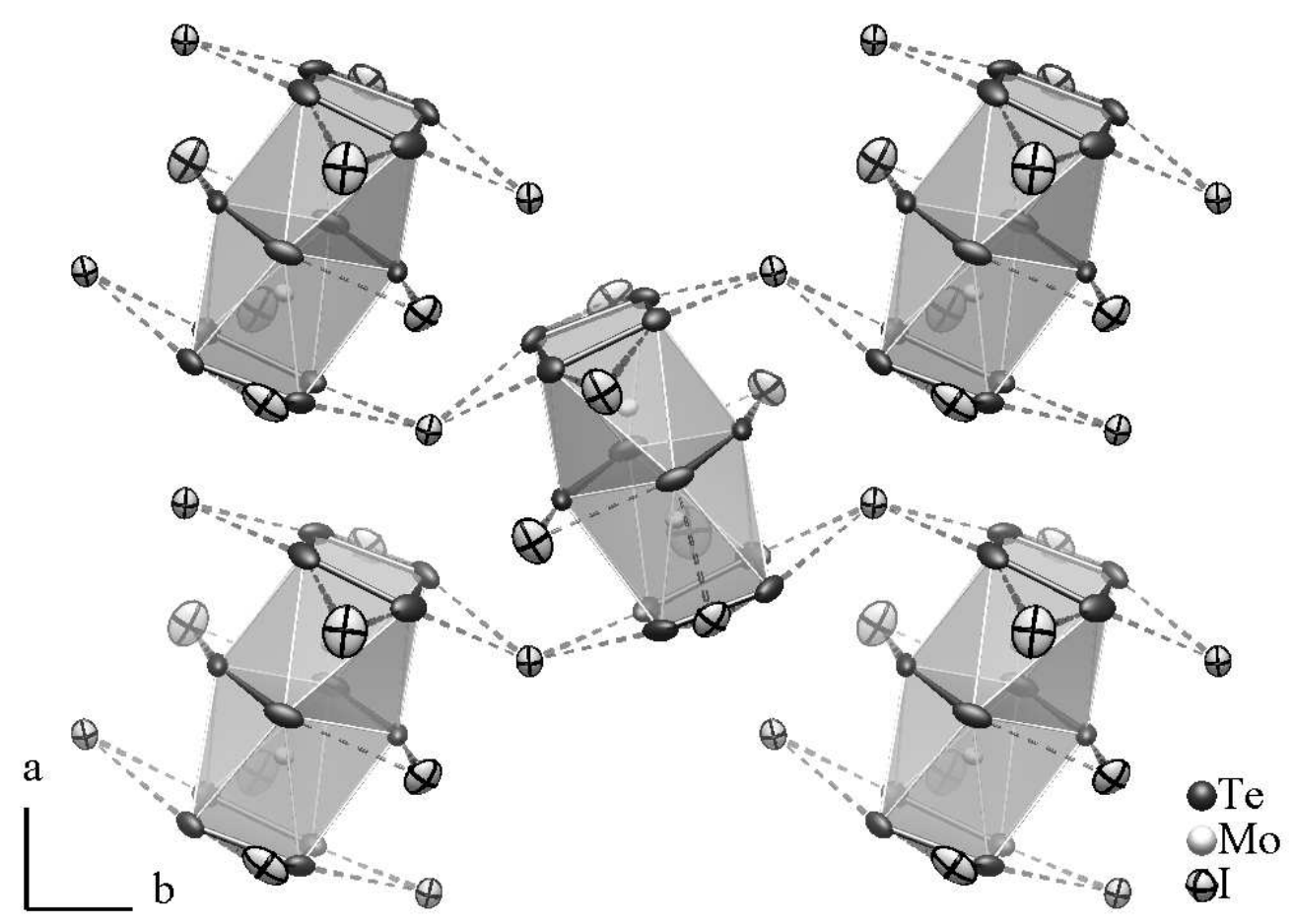

Figure 2. Section of the crystal structure of $\left[\mathrm{Mo}_{2} \mathrm{Te}_{12}\right] \mathrm{I}_{6}$. The ellipsoids represent $95 \%$ probability at $150(2) \mathrm{K}$. $265 \times 187 \mathrm{~mm}(96 \times 96 \mathrm{DPI})$ 


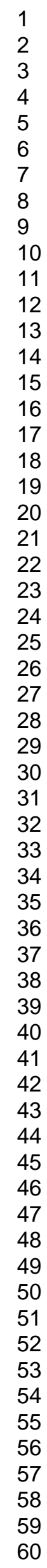

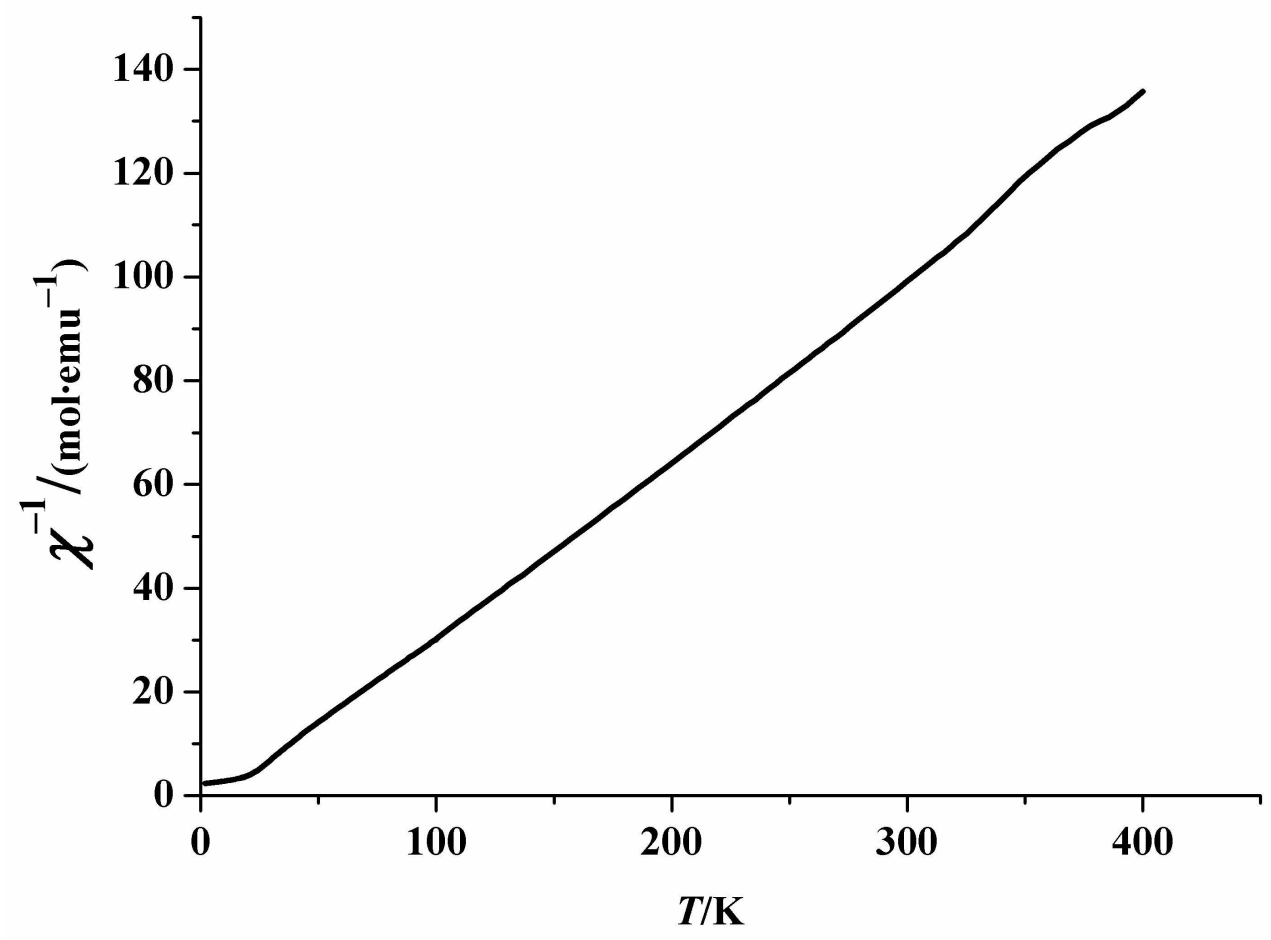

Temperature dependence of reciprocal molar susceptibility for $\left[\mathrm{Mo}_{2} \mathrm{Te}_{12}\right] \mathrm{I}_{6}$ in a magnetic field of $H=$ $35 \mathrm{kOe}$. $242 \times 175 \mathrm{~mm}$ ( $300 \times 300$ DPI) 